\title{
SALMONELLA SPECIES ON MEAT CONTACT SURFACES AND PROCESSING WATER IN SOKOTO MAIN MARKET AND ABATTOIR, NIGERIA
}

\author{
Olufemi Oludayo Faleke ${ }^{1}$, Kelvin Olatimilehin Jolayemi ${ }^{1}$, Yvvone Ogah Igoh ${ }^{1}$, \\ Abdurrahman Hassan Jibril ${ }^{1}$, Julius Olaniyi Ayedun ${ }^{2}$ \\ ${ }^{1}$ Department of Veterinary Public Health and Preventive Medicine, Faculty of Veterinary \\ Medicine Usmanu Danfodiyo University, Sokoto State, Nigeria \\ ${ }^{2}$ Department of Veterinary Public Health and Preventive Medicine, Faculty of Veterinary \\ Medicine University of Ilorin, Kwara State Nigeria
}

Received 14 October 2016; Received in revised form 22 December 2016; Accepted 30 December 2016

\begin{abstract}
This study was carried out to determine Salmonella contamination of food contact surfaces and processing water in meat, fish and poultry processing units in Sokoto State, Nigeria. A total of $200 \mathrm{swab}$ (100 from abattoir and 100 from poultry and fish markets) and 60 processing water samples (30 from abattoir and 30 from poultry and fish markets) were collected between May to August 2015. Cultural isolation, bio-typing and sero-grouping using Salmonella Sero-Quick Group Kit was conducted to analyse the samples. Seventy-five $(75 / 260,28.8 \%)$ of the total samples were positive to Salmonella by cultural isolation and bio-typing. Thirty $(30 / 130 ; 23.1 \%)$ of samples collected in abattoir and 45 $(45 / 130 ; 34.6 \%)$ of those collected from poultry and fish markets were positive for Salmonella respectively. Sero-groups D+Vi (Salmonella Typhi), B (Salmonella Paratyphi B, Salmonella Typhimurium) and C (Salmonella Paratyphi C, Salmonella Cholerae suis) were identified as the prevailing sero-groups in this study. Sero-group D+Vi has the highest prevalence $(73.3 \%$; $55 / 75)$ from the positive bio-typing isolates. This study revealed the presence of contaminating and pathogenic Salmonella on food contact surfaces and processing water in the meat retail markets, indicating there is an urgent need to improve on the hygienic status of retail meat, poultry and fish markets.
\end{abstract}

Key words: Salmonella, meat contact surface, sero-group, abattoir, Nigeria

\section{INTRODUCTION}

There has been a significant interest in studying the biology of Salmonella because these bacteria are among the leading causes of foodborne illnesses around the globe (1). Over 2500 known serotypes, of Salmonella have been isolated so far. However, Salmonella enteric serovars Enteritidis and Typhimurium are the most frequently associated with food poisoning leading to illness in humans

\footnotetext{
Corresponding author: Dr. Abdurrahman Jibril, PhD

E-mail address: jibrilah50@yahoo.com

Present address: Department of Veterinary Public Health

and Preventive Medicine, Faculty of Veterinary Medicine

Usmanu Danfodiyo University, Sokoto State, Nigeria

Phone: ++2348037735131

Copyright: (C) 2017 Faleke O.O. This is an open-access article published under the terms of the Creative Commons Attribution License which permits unrestricted use, distribution, and reproduction in any medium, provided the original author and source are credited.

Competing Interests: The authors have declared that no competing interests exist.

Available Online First: 7 January 2017

Published on: 15 March 2017

http://dx.doi.org/10.1515/macvetrev-2017-0011
}

when these organisms are ingested through raw or improperly processed food (3).

In many industrialized countries, the incidence of salmonellosis in humans and the prevalence of Salmonella in many food products have increased significantly over the last twenty years (2). This bacterium is broad host-spectrum, and can be isolated from a wide range of animal species, including birds and reptiles (4). The animals usually are healthy carriers, and contaminated food plays an important role in the epidemiology of salmonellosis. Salmonella can survive for a long time in the environment. Humans are usually infected through consumption of contaminated foods of animal origin (2). In human and animal cases it is an enteric disease of varying severity, usually involving diarrhea (4).

Meat contact surfaces serve as sources of food contamination, and typical food contact surfaces in Nigerian retail markets include the meat handler's 
hands and outer garments, slaughtering hall, wooden tables (abattoir and market), cutting knives, weighing scales, water holding utensils such as metal buckets and plastic containers, wheelbarrows and vehicles for conveying meat $(5,6,7)$. Recently, it has been indicated that, many bacterial species are indigenous part of seafood, but they can also be found on the food processing surfaces, where they can subsequently contaminate the products. (8)

During the processing of poultry carcasses, microbial contamination inevitably occurs as a consequence of the processing procedures used. At each stage of the process, ample opportunity exists for contamination of the carcass by microorganisms from the processing plant or by cross-contamination from other birds (2).

Sanitary monitoring of food contact surfaces is a powerful tool for the detection of risks associated with the production, manufacture and consumption of food (9). This study evaluated the level of Salmonella contamination on meat contact surfaces in the study area.

\section{MATERIAL AND METHODS}

\section{Study area}

Sokoto is the capital of Sokoto State, located at $13^{\circ} \mathrm{N}$ and longitude $30^{\circ} \mathrm{E}$ and $90^{\circ} \mathrm{E}$ in the North Western part of Nigeria. It lies roughly between longitude $30^{\circ} \mathrm{E}$ and $15^{\circ} \mathrm{E}$ of Greenwich and between $4^{\circ} \mathrm{N}$ and $14^{\circ} \mathrm{N}$ of the equator. It covers approximately an area of 56,000 square kilometers (10). Sokoto metropolis is located in the Sudan savannah zone grass vegetation, sandy soil and humidity, which is usually below $40 \%$ except in few wet months when it approaches $60 \%(11)$.

\section{Sampling procedure}

Samples were collected from contact surfaces and processing water in Sokoto metropolitan abattoirs, poultry processing units and fish markets. Contact surfaces comprise of slaughtering halls, wooden tables, cutting knives, weighing scales, water holding utensils such as metal buckets and plastic containers, wheelbarrows and vehicles for conveying meat. The Compendium of methods for the microbiological examination of foods (12) was used, with $10-15 \mathrm{~cm}^{2}$ surface area of each contact surface was used for taking swabs from the contact surfaces. A total of 100 meat contact surfaces, 30 samples of meat processing water, 100 poultry meat and fish contact surfaces and 30 samples of processing water were collected from ruminant abattoirs, poultry processing units and fish markets respectively. The sample swab head was rinsed in sterile $10 \mathrm{ml}$ of $0.1 \%$ buffered peptone water and transported to the Veterinary Public Health and Preventive Medicine of Usmanu Danfodiyo University, Sokoto for isolation and identification.

\section{Media preparation}

Enrichment was done with Rapapport Vassiliadis Soya broth (RVS Himedia ${ }^{\mathrm{TM}}$ ). All the media used for bacterial culture were prepared in the laboratory according to the manufacturers' instructions and include, Salmonella Shigella Agar (SS Himedia ${ }^{\mathrm{TM}}$ ), Triple Sugar Iron (Antec Diagnostic Products ${ }^{\mathrm{TM}} \mathrm{UK}$ ), Urease Agar (Oxoid LTD, London), Simon's citrate Agar (Himedia ${ }^{\mathrm{TM}}$ ), Nutrient Agar (Oxoid LTD, London).

\section{Bacterial isolation and identification}

A loopful of each broth inoculum was streaked on Salmonela Shigella agar and the culture plates were incubated at $37^{\circ} \mathrm{C}$ for $24-48 \mathrm{hrs}$, while growth was observed for typical colonial morphology of Salmonella (13). Standard biochemical tests were used to identify Salmonella among suspect isolates using conventional methods. Test conducted include Triple sugar iron (TSI), urease test, oxidase test, Citrate test, Indole test. Isolates with colorless transparent, dark centered colonies were identified as Salmonella spps. On bio-typing isolates that were negative to TSI, Urease, Indole and Citrate were considered to be Salmonella.

\section{Sero-grouping}

Positive isolates for cultural identification and bio-typing were subjected to sero-grouping using Salmonella Sero-Quick Group screening kit obtained from Staten's Serum Institute (SSI), Copenhagen, Denmark for identifying Salmonella isolates according to the sero-group level. The kit includes anti-sera against the most common serogroups of Salmonella A-G and the capsule antigen $\mathrm{Vi}$. The sero-group A and the Vi antigens are not common but expressed by the clinical important serotypes S. Typhi 9, 12\{Vi\};d) and S. Paratyphi $\{1$, $2,12 ; \mathrm{a}\}$

\section{Data analysis}

The data obtained from this study was entered and stored in Microsoft Excel ${ }^{\circledR} 2010$ using descriptive statistics, and they were analysed using Graph Pad Prism. Categorical variables were evaluated using Chi square and Fishers exact 
test to check for association between variables and percentage positive of Salmonella. Values of $\mathrm{p}<0.05$ at $95 \%$ confidence interval were considered significant.

\section{RESULTS}

As indicated in Table 1, out of one hundred (100) samples obtained from the meat contact surfaces $20(20 \%)$ were found to be positive for Salmonella. Emergency slaughtering floor had the highest number of positive isolates $6(60 \%)$, while no isolates were recovered from camel slaughtering floor, slaughtering knives and knives used at the retail market $(0 \%)$. There is significant difference ( $p=0.02$ ) between food contact surfaces in the abattoir and Salmonella contamination. Thirty (30) processing water samples were collected and $10(33.3 \%)$ were positive for Salmonella. Three serotypes of Salmonella from meat contact surfaces were isolated which are Serotype D+Vi, Serotype $\mathrm{B}$ and Serotype C 1 (Table 2). Serotype D+Vi is the most common isolate among the three isolates.

As indicated in Table 3, a total of 45 positive sample of Salmonella (34.6\%) were obtained from food contact surfaces and processing water in poultry and fish markets. The chicken and fish bowls had the highest number of positive isolates 9/15
$(60.0 \%)$ and $7 / 15(45 \%)$ respectively, while chicken knives had the lowest 1/5 (20\%). However, there is no statistical significance differences among the contact surfaces $(p=0.06)$. The fish processing water showed $66.7 \%$ of Salmonella isolates, while the poultry processing water had $13.3 \%$ positive isolates. There is a statistical significant difference between poultry and fish processing water $(p=0.007)$. Out of 45 positive isolates that were subjected to serotyping, 39 isolates tested positive to the D sero-group (Salmonella entrica serotype Enteritidis) and 12 out of these D sero-group were the virulent $\mathrm{Vi}$ antigen (Salmonella Typhi). While the remaining 6 tested positive to the B sero-group (Salmonella enteric serotype Typhimurium) (Table 4).

\section{DISCUSSION}

Good Hygienic Practices (GHP) are essential to ensure food safety. They are required by law under national and international food hygiene regulations and are frequently considered as prerequisites to food safety systems based on Hazard Analysis and Critical Control Point (HACCP). Compromising good hygiene almost always results in establishment and proliferation of pathogenic as well as spoilage microorganisms on the processing and storage food contact surfaces (9). In this study,

Table 1. Distribution of Salmonella spp. on selected meat contact surfaces and processing water in Sokoto, Nigeria

\begin{tabular}{|c|c|c|c|}
\hline Sources & $\begin{array}{c}\text { Number of sample } \\
\text { collected }\end{array}$ & $\begin{array}{c}\text { Number of samples } \\
\text { positive }\end{array}$ & Percentage $(\%)$ \\
\hline${ }^{*}$ Cattle slaughtering floors & 15 & 2 & 13.33 \\
\hline *Wheelbarrows & 12 & 2 & 16.66 \\
\hline *Camel slaughtering knives & 7 & 0 & 0 \\
\hline *Cattle slaughtering knives & 10 & 2 & 20 \\
\hline *Camel slaughtering floor & 5 & 0 & 0 \\
\hline *Sheep and goat slaughtering floor & 12 & 4 & 33.33 \\
\hline *Sheep and goat slaughtering knives & 9 & 3 & 33.33 \\
\hline *Market tables & 10 & 1 & 10 \\
\hline *Market knives & 10 & 0 & 0 \\
\hline *Emergency slaughtering floor & 10 & 6 & 60 \\
\hline Subtotal & 100 & 20 & 20 \\
\hline$\dagger$ Processing water for sheep and goat carcasses & 15 & 5 & 33.33 \\
\hline$\dagger$ Processing water for cattle carcasses & 15 & 5 & 33.33 \\
\hline Subtotal & 30 & 10 & 33.33 \\
\hline Total & 130 & 30 & 23.1 \\
\hline
\end{tabular}


Table 2. Sero-grouping of Salmonella spp. isolates from meat contact surfaces and processing water in Sokoto, Nigeria

\begin{tabular}{|c|c|c|c|c|c|c|c|c|}
\hline \multirow{2}{*}{ Sources } & \multicolumn{7}{|c|}{ Number of positive antigens } & \multirow{2}{*}{ Serotype } \\
\hline & $\mathbf{D}+\mathbf{V i}$ & B & $\mathbf{C}$ & $\mathbf{E}$ & G & $\mathbf{F}$ & $\mathbf{A}$ & \\
\hline Cattle slaughtering floors & 2 & & & & & & & $\begin{array}{l}\text { Salmonella Typhi, } \\
\text { Salmonella Enteritidis }\end{array}$ \\
\hline Wheelbarrows & 2 & & & & & & & $\begin{array}{l}\text { Salmonella Typhi, } \\
\text { Salmonella Enteritidis }\end{array}$ \\
\hline \multicolumn{9}{|l|}{ Camel slaughtering knives } \\
\hline Cattle slaughtering knives & 2 & & & & & & & $\begin{array}{l}\text { Salmonella Typhi, } \\
\text { Salmonella Enteritidis }\end{array}$ \\
\hline $\begin{array}{l}\text { Sheep and goat slaughtering } \\
\text { floor }\end{array}$ & 3 & 1 & & & & & & $\begin{array}{l}\text { Salmonella Typhi, } \\
\text { Salmonella Enteritidis } \\
+ \\
\text { Salmonella Paratyphi B, } \\
\text { Salmonella Typhimurium }\end{array}$ \\
\hline $\begin{array}{l}\text { Sheep and goat slaughtering } \\
\text { knives }\end{array}$ & 3 & & & & & & & $\begin{array}{l}\text { Salmonella Typhi, } \\
\text { Salmonella Enteritidis }\end{array}$ \\
\hline Market tables & & 1 & & & & & & $\begin{array}{l}\text { Salmonella Paratyphi B, } \\
\text { Salmonella Typhimurium }\end{array}$ \\
\hline $\begin{array}{l}\text { Emergency slaughtering } \\
\text { floor }\end{array}$ & 4 & 1 & 1 & & & & & $\begin{array}{l}\text { Salmonella Typhi, } \\
\text { Salmonella Enteritidis } \\
+ \\
\text { Salmonella Paratyphi B, } \\
\text { Salmonella Typhimurium } \\
+ \\
\text { Salmonella Cholera suis, } \\
\text { Salmonella Paratyphi C }\end{array}$ \\
\hline Total & 16 & 3 & 1 & & & & & \\
\hline
\end{tabular}

Table 3. Distribution of Salmonella spp. on selected meat contact surfaces and processing water in poultry and fish market in Sokoto, Nigeria

\begin{tabular}{|c|c|c|c|}
\hline Sources & $\begin{array}{c}\text { Number of samples } \\
\text { collected }\end{array}$ & $\begin{array}{c}\text { Number of positive } \\
\text { samples }\end{array}$ & $\begin{array}{l}\text { Percentage positive for } \\
\text { Salmonella }(\%)\end{array}$ \\
\hline *Chicken cages & 20 & 6 & 30 \\
\hline *Chicken floor & 20 & 6 & 30 \\
\hline *Chicken bowls & 15 & 9 & 60 \\
\hline *Chicken knives & 5 & 1 & 20 \\
\hline Subtotal & 60 & 22 & 36.7 \\
\hline *Fish bowls & 15 & 7 & 46.7 \\
\hline *Fish tables & 15 & 4 & 26.7 \\
\hline *Fish knives & 10 & 0 & 0 \\
\hline Subtotal & 40 & 11 & 27.5 \\
\hline$\dagger$ Fish water & 15 & 10 & 66.7 \\
\hline$\dagger$ Chicken water & 15 & 2 & 13.3 \\
\hline Subtotal & 30 & 12 & 40.0 \\
\hline Total & 130 & 45 & 34.6 \\
\hline
\end{tabular}


Table 4. Sero-grouping of Salmonella spps isolates from meat contact surfaces and processing water in poultry and fish market, Sokoto Nigeria

\begin{tabular}{|c|c|c|c|c|c|c|c|c|c|c|}
\hline \multirow[b]{2}{*}{ Sample identification } & \multirow[b]{2}{*}{$\begin{array}{c}\text { Number of } \\
\text { positive samples }\end{array}$} & \multicolumn{8}{|c|}{ Sero-groups } & \multirow[b]{2}{*}{ Serotypes } \\
\hline & & D & $\mathbf{V i}$ & B & C & $\mathbf{E}$ & $\mathbf{G}$ & $\mathbf{F}$ & $\mathbf{A}$ & \\
\hline Chicken Cage & 6 & 6 & 2 & & & & & & & $\begin{array}{l}\text { S. Enteritidis and } \\
\text { S. Typhi. }\end{array}$ \\
\hline Chicken Floor & 6 & 5 & 2 & 1 & & & & & & $\begin{array}{l}\text { S. Enteritidis, } \\
\text { S. Typhi and } \\
\text { S. Typhimurium. }\end{array}$ \\
\hline Chicken Bowl & 9 & 8 & 3 & 1 & & & & & & $\begin{array}{l}\text { S. Enteritidis, } \\
\text { S. Typhi and } \\
\text { S. Typhimurium. }\end{array}$ \\
\hline Chicken knife & 1 & 1 & 1 & - & & & & & & $\begin{array}{l}\text { S. Enteritidis and } \\
\text { S.Typhi. }\end{array}$ \\
\hline Chicken Water & 2 & 2 & 1 & - & & & & & & $\begin{array}{l}\text { S. Enteritidis and } \\
\text { S.Typhi. }\end{array}$ \\
\hline Fish Bowl & 7 & 6 & - & 1 & & & & & & $\begin{array}{l}\text { S. Enteritidis and } \\
\text { S. Typhimurium. }\end{array}$ \\
\hline Fish Table & 4 & 3 & - & 1 & & & & & & $\begin{array}{l}\text { S.Enteritidis and } \\
\text { S. Typhimurium. }\end{array}$ \\
\hline Fish Knife & 0 & & & & & & & & & \\
\hline Fish Water & 10 & 8 & 3 & 2 & & & & & & $\begin{array}{l}\text { S. Enteritidis, } \\
\text { S. Typhi and } \\
\text { S. Typhimurium. }\end{array}$ \\
\hline Total & 45 & 39 & 12 & 6 & & & & & & \\
\hline
\end{tabular}

we used conventional bacterial culture isolation and bio-typing, to detect Salmonella contamination of meat, poultry and fish contact surfaces and processing water. Serological evidence of the strains that served as source of contamination was also identified. High number $(23.1 \%)$ of food contact surfaces and processing water in abattoirs in the study area showed Salmonella contamination. This is partly due lack of adherence to good hygienic practices in the processing of meat and largely due to poor animal husbandry and management practices on the farms. Contamination of surfaces may also occur from the water used in washing and processing the meat, because there is no adequate provision of good quality water in the abattoir. In a recent study conducted on the bacteriological quality of raw meat displayed for sale at Sokoto, Nigeria, $8.2 \%$ of these surfaces were contaminated with Salmonella (14). Higher prevalence have been reported from several studies, including $26 \%$ in meat products (15) and $23.3 \%$ prevalence (16) in Egypt.

Poultry contact surfaces showed $36.7 \%(22 / 60)$ Salmonella contamination, while chicken knives have the lowest 1/5 (20\%) level of contamination among other poultry contact surfaces. However, the prevalence is less when compared with the report of Ishola and Taiwo (17) that showed 66.7\% on chicken knives among frozen poultry retailers in Oyo State, Nigeria. This contamination may have resulted because the knives used are not been changed nor rinsed for the entire day's operation, hence the higher microbial level due to the accumulation of microorganisms and likely, biofilms on their surfaces. Cleaning and sanitation of food-processing surfaces with short intervals was proposed as an effective approach to prevent or limit biofilms formation (18).

The high number of Salmonella isolates (66.7\%) and $(13.3 \%)$ obtained from the fish and meat processing water respectively is alarming and could be a potential source of contamination to the meat and fishes. This could be due to the fact that water used in the processing of meat is sourced from nearby streams and wells that have possibly been contaminated with municipal sewage.

Considering that Salmonella is not a component of the normal fish flora, this indicates that contamination of fish is a result of fecal contamination through polluted water, infected food 
handlers or cross-contamination during production or transportation (19). Therefore it is likely that water may have acted as a vehicle of transmission of this microorganism. This study revealed that Salmonella Typhi was the most frequent isolate. However, in the recent epidemiological studies was indicated that $S$. Enteritidis and $S$. Infantis are most frequently isolated from poultry flocks in southern Bačka and Srem region in Serbia (1). Salmonella Typhi is a human pathogen, having high levels of it could be an indication of fecal contamination of these surfaces and processing water. Contamination of these surfaces may be from the butchers, which could arise from the use of ungloved hands during dressing and processing of the carcass in the slaughtering hall. Also, the footwear's used by the butchers could serve as a vehicle for faecal contamination, because dressing and processing of carcasses takes place on the open floor in the slaughtering hall.

Salmonella species such as Salmonella Typhi is a bacterium that causes typhoid fever (enteric fever), an acute, life-threatening febrile illness (20). The disease is a cause for concern and a major public health problem in developing countries; especially in Nigeria due to poor sanitary conditions, lack of inadequate portable water, weak regulatory systems, lack of financial resources to invest in safer equipment and lack of education of meathandlers (20). It is mainly transmitted through food or drink or water, contaminated with urine or faeces of infected people or a chronic carrier $(20,21)$.

\section{CONCLUSION}

Human Salmonella as identified in the study posed a major public health concern in the study area. The competent authorities for the hygiene in the abattoirs and market need to awaken to their responsibility and raise the public awareness about standard operating hygienic practices.

\section{CONFLICT OF INTEREST STATEMENT}

The authors declared that they have no potential conflict of interest with respect to the authorship and/or publication of this article.

\section{ACKNOWLEDGEMENT}

The authors will like to appreciate the contribution of the management of the abattoir as well as staff of the Central Research Laboratory of Faculty of Veterinary Medicine, Usmanau Danfodiyo University for their technical support.

\section{REFERENCES}

1. Vehlner M. (2016). Mechanisms of resistance to quinolones and epidemiological significance of Salmonella spp. Acta Veterinaria-Beograd 66 (2): 147-159.

https://doi.org/10.1515/acve-2016-0013

2. Javadi, A., Safarmashaei S., Ghadimi, R. (2011). Study on Salmonella contamination in poultry lean meat and meat with skin in Tabriz slaughter houses. African Journal of Biotechnology 13(1): 181-184. https://doi.org/10.5897/AJB11.3500

3. Panisello, P. J., Rooney, R., Quantick, P.C., StanwellSmith, R. (2000). Application of food-borne disease outbreak data in the development and maintenance of HACCP systems. Int J Food Microbiol. 59, 221234.

https://doi.org/10.1016/S0168-1605(00)00376-7

4. Bean, N.H., Goulding, J.S., Daniels, M.T., Angulo, F.J. (1997). Surveillance for food born disease outbreaks-United States, 1988-1992. J. Food Prot. 60, 1265-1286.

https://doi.org/10.4315/0362-028X-60.10.1265

5. Marriott, J.A. (2004). Microbial problems in handling and storage of fresh meats. Journal of Applied Bacteriology 7, 433-441.

6. Biswas, A.K., Kondaiah, A.K., Anjaneyulu, A.S., Mandal, P.K. (2011). Causes, concerns, consequences and control of microbial contaminants in meat. International Journal of Meat Science 1, 2735 .

https://doi.org/10.3923/ijmeat.2011.27.35

7. Omuruyi, I.M., Wogu, M.D., Eraga, E.M. (2011). Bacteriological quality of beef-contact surfaces, air microflora and wastewaters from major abattoirs located in Benin City, Southern Nigeria. International Journal of Biosciences 1: 57-62.

8. Vogel, F.B., Huss, H.H., Ojeniyi, B., Ahrens, P., Gram, L. (2001). Elucidation of Listeria monocytogenes contamination routes in cold smoked salmon processing plants detected by DNAbased typing methods. Apply Environ. Microbiol. 67(6): 2586-2595.

https://doi.org/10.1128/AEM.67.6.2586-2595.2001

PMid:11375167 PMCid:PMC92911 
9. Ponnerassery, S. S., Aliya A., Nasser, A., Sami, A., Humaid, A. (2013). Evaluation of Food Contact Surface Contamination and the Presence of Pathogenic Bacteria in Seafood Retail Outlets in the Sultanate of Oman. Advance Journal of Food Science and Technology 5 (2): 77-83.

10. Anon (2001): Sokoto State-the seat of the Caliphate. In: Sokoto State Government Dairy. pp 2-8.

11. Iloeje, N.P. (1971). Where is Nigeria and who are the Nigerians? In: A new Geography of Nigeria, Vol. 1, pp 14.

12. American Public Health Association (1992). Compendium of methods for the microbial examination of foods. 3rd rev. ed. C. Vanderzant and D.F. Splitt stoesser, Washington, USA.

13. Santos, R.L., Tsolis, R.M., Baumler, A.J., Adams, L.G. (2003). Pathogenesis of Salmonella-induced enteritis. Brazilian Journal of Medical and Biological Research. 36, 3-12. https://doi.org/10.1590/S0100-879X2003000100002

14. Salihu, M.D, Magaji, A.A., Garba, B. (2013). Bacteriological quality of raw meat displayed for sale at Sokoto, Sokoto state, Nigeria. Scientific Journal of Microbiology 2 (7): 134-139.

15. Karmi, M. (2013). Prevalence of Salmonella in Meat Products. Global Veterinaria 11 (5): 685 688.
16. Essa, H.H., Manaa, A.M., Makar, N.H., Sayed, S.M. (2009). Studies on Salmonella and E.coli in some meat products (beef burgers and luncheon) sold in Assiut city. Assiut Vet. Med. J. 121, 211-216.

17. Ishola, D. O., Taiwo, A. G. (2014). Frozen retail poultry meat contact surfaces as sources of Salmonella and Escherichia coli contamination in Ibadan, Oyo State, Nigeria. American Journal of Infectious Diseases and Microbiology 2(4): 81-85. https://doi.org/10.12691/ajidm-2-4-2

18. Lindsay, D., Brozel, V.S., von Holy, A. (2005). Spore formation in Bacillus subtilis biofilms. J Food Prot. 68, 860-865.

https://doi.org/10.4315/0362-028X-68.4.860 PMid:15830685

19. Lunestad, B.T., Borlaug, K. (2009). Persistence of Salmonella enterica serovar agona in oil for fish feed production. Journal of Aquaculture Feed Science and Nutrition $13,73-77$.

20. CDC, Salmonella Surveillance: Annual Summary (2004). US Department of Health and Human Services, CDC: Atlanta, Georgia. (2005).

21. Ibekwe, A.C., Okonko, I.O., Onunkwo, A.U., Donbraye, E., Babalola, E.T., Onoja, B.A. (2008). Baseline Salmonella agglutinin titres in apparently healthy freshmen in Awka, South Eastern, Nigeria. Scientific Research and Essay 3 (9): 225-230. 